\title{
The Implementation of Management Training Model Diploma in Mechanical Engineering, Faculty of Engineering, State University of Medan
}

\author{
Leni Purwati ${ }^{1}$, Rosmala Dewi ${ }^{2}$, Darwin $^{3}$ \\ Postgraduate Students at Universitas Negeri Medan, Indonesia ${ }^{1}$ \\ Jurusan Psikologi Pendidikan dan Bimbingan Universitas Negeri Medan, Indonesia ${ }^{2}$ \\ Jurusan Pendidikan Teknik Bangunan Universitas Negeri Medan, Indonesia ${ }^{3}$ \\ lenipurwati1975@gmail.com
}

\begin{abstract}
This research aims to determine the Implementation of Training Management Models for Diploma (D3) Students in Mechanical Engineering, Faculty of Engineering, The State University of Medan. This research uses descriptive method with a qualitative approach. Data collection techniques used were field studies in the form of observation, interviews, and documentation with the Head of Study Program, Head of Workshop, Students and Employees of the Diploma in Mechanical Engineering at the Faculty of Engineering, Universitas Negeri Medan related to management training in the Diploma (D3) in Mechanical Engineering Universitas Negeri Medan. The results of the study showed that the training management model in Diploma (D3) of Mechanical Engineering, Faculty of Engineering, Universitas Negeri Medan had not been well-organized planning, because the training management itself was still attached to the product design courses, this was due to the absence of a stand-alone training program independently, both internally and in collaboration with outside training institutions. But the implementation is good because students are already skilled in using tools and drawing designs. It is therefore recommended to establish management training that is independent and separate from the course, so that the training carried out at Diploma (D3) of Mechanical Engineering, Faculty of Engineering Unimed is more effective and in accordance with the expected achievements.
\end{abstract}

Keywords: Model Implementation, Training Management.

\section{Introduction}

The main problem facing our nation, especially in the field of education in the face of globalization is the low level of competence and quality of human resources. The development of a technology is inseparable from the potential of human resources who have the skills to produce new products creatively and innovatively. Qualified population is a supporting factor for the success of development Improved workforce skills are obtained through structured training, which for the production process will not be able to work optimally without being accompanied by providing broader and deeper training. Training shows that activities are planned to achieve mastery of skills, knowledge, and positive attitudes. For this reason, training is usually coupled with development that is more focused on improving decision-making abilities and broadening human relations for top management and middle management. 


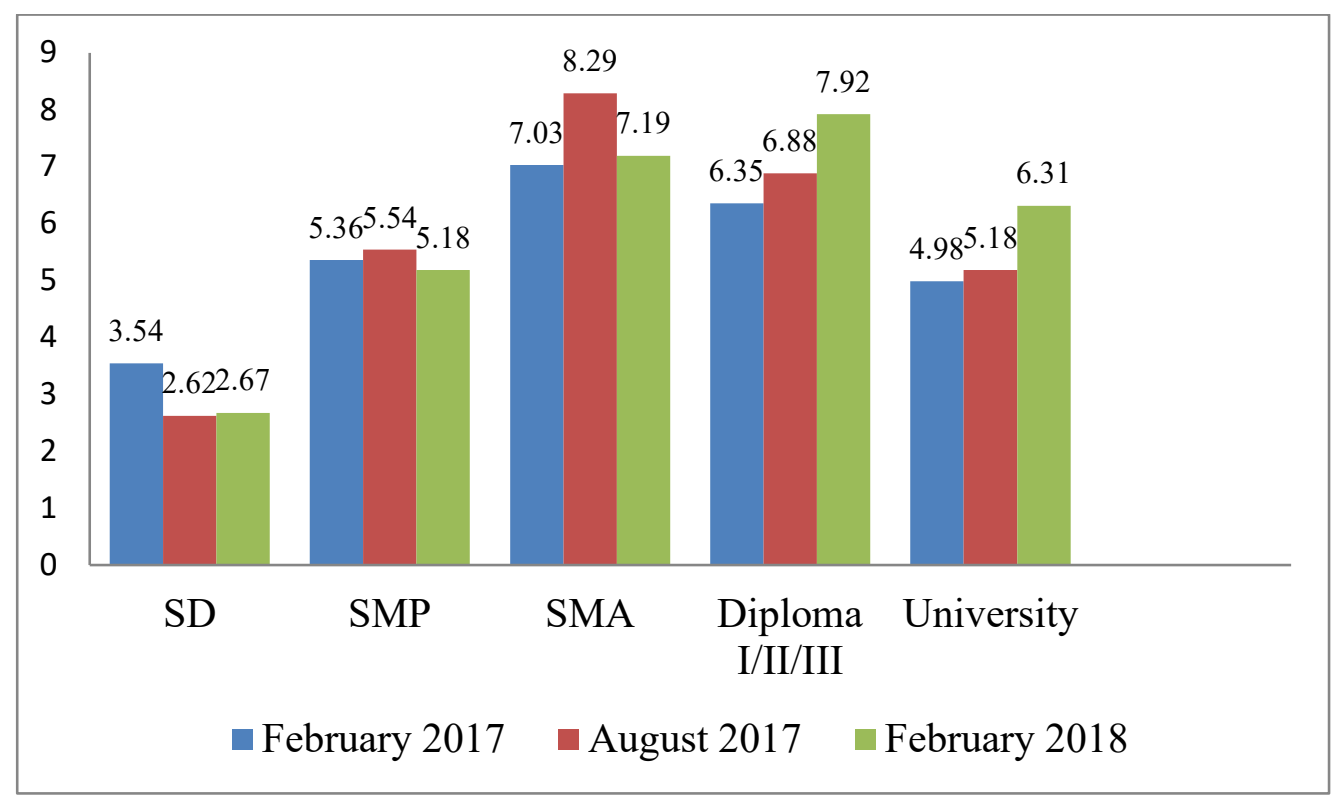

Fig 1. Proportion of Indonesian Workers 2018

(Source: Badan Pusat Statistik, 2018)

\section{Research Method}

This research is a descriptive qualitative research where in the future it will find the widest knowledge about a particular object by gathering as much information as possible in order to describe things that are specific to the object under study. To facilitate the design of this study based on the problems and literature review described previously. Qualitative methodology is a research procedure that produces description data in the form of written or oral words from people and observable behavior. The object of study in this research is the implementation of the management training model of the Diploma Three students of Mechanical Engineering, Faculty of Engineering, Universitas Negeri Medan.

Analysis of the data in this study leads to descriptive analysis or analysis that describes factual information. For this reason, data analysis techniques use qualitative descriptive analysis techniques and do not test the hypothesis or the relationship between variables. This qualitative descriptive analysis is to answer the research questions that have been prepared in the previous chapter. The level of descriptive analysis depth in this study only reached the presentation of facts and systematic description of data relating to information and the phenomenon of the implementation of the management training model of the Diploma Three students of Mechanical Engineering, Medan State University. The next step, after the data is collected, then the data needs to be analyzed. Data analysis consists of 3 (three) activities that occur simultaneously namely data reduction, data presentation, drawing conclusions / verification. So in this research the data analysis is done by using an interactive model or inductive analysis techniques namely: 1) data collection; 2) data reduction; 3) data presentation and; 4) drawing conclusions. 


\section{Results and Discussion}

Based on the management function, the management training found in the Universitas Negeri Medan D3 Mechanical Engineering Diploma Program is as follows:

1. Planning

a) The training activities have been designed through the RPS (Semester Program Design) and are in accordance with the IQF curriculum, but have not fully designed the stages of the training implementation that will be carried out throughout the meeting. Material supporting the training activities of product design courses has not been arranged properly, so students are required to search for literature independently through assignments given by lecturers or through courses in the previous semester.

b) Providing training in product design courses is in accordance with the goals and vision and mission of the D3 Universitas Negeri Medan Mechanical Engineering Study Program, which is to create students who are skilled and competitive in the field of production machinery.

c) The evaluation is still using the Assessment Standards for courses namely DPNA, not using the assessment for student competency tests.

2. Organizing

a) Determination of competency-based training instructors has been done based on the expertise and experience of the instructors.

b) Facilities and infrastructure such as the availability of practical materials and machine tools making equipment are quite complete, but the practice room lighting is still lacking.

c) There are no prerequisites for students who will participate in product design training, so students who have not passed the courses below are allowed to attend the training.

3. Implementation

a) The training has been carried out using the guided inquiry method guided by the lecturer as an instructor.

b) Objective student competency information is not neglected objectively, even though this information is important for teachers to condition participants according to their competencies in training activities.

c) Allocation of training time carried out is in accordance with the RPS, which is as many as 16 times meeting 100 minutes ( 2 credits) each

4. Control

a) The lecturer performance has been carried out by the D3 Unimed Mechanical Engineering Study Program

b) Feedback on student activities has not been clearly detailed

c) Tracer Study is still carried out manually so there is no tracer study system

Based on the analysis of trends obtained by researchers, it can be concluded that the learning model that has been applied is quite good, but to improve student competence in designing products requires a certain training model, because training requires a certificate of competency test results as a companion diploma. To improve student competency in product design, wellorganized training is needed, starting from planning, organizing, implementing, to controlling. Existing training management must also be adjusted to the Level 5 National Work Qualification Standards (SKKNI) Training Methodology Subdivision. The facilities and facilities that support the training in the Universitas Negeri Medan D3 Mechanical Engineering Study Program are complete enough, namely by having enough machining tools to be used by all students in one 
class, totaling approximately 15 people. The workshop / workshop room is also spacious and far from noise, and is able to reduce the noise from the workshop.

Basically the training has been going well, but several things that need to be developed are the making of practicum modules, with the aim that students can design the production machine more directed. Students are already skilled enough in designing products, but have not been able to create appropriate production machines in society. This is one proof that training modules are really needed so that students do not only rely on their creativity, but can also be guided by existing literature, such as work modules. Based on the analysis obtained by the researcher, it can be concluded the results of internal validation that the design of training management in Diploma Three of Mechanical Engineering, Faculty of Engineering, State University of Medan can be seen that management training shows that planning and implementation are included in the already good category. All have been carried out in accordance with what has been expected by the study program. Although overall it can be said to be in a good category but in its implementation, there are still some deficiencies in certain aspects.

Based on the results of the study and studied in theory it can be concluded that the implementation of the training management model is going well, this is seen from several aspects which include the achievement of targets, product completion time, and customer satisfaction. As confirmed by the results of the interview, it has been going well, but there are several evaluation programs that must be carried out involving all the management parties, study programs, production unit heads, lecturers, students and staff in order to improve quality

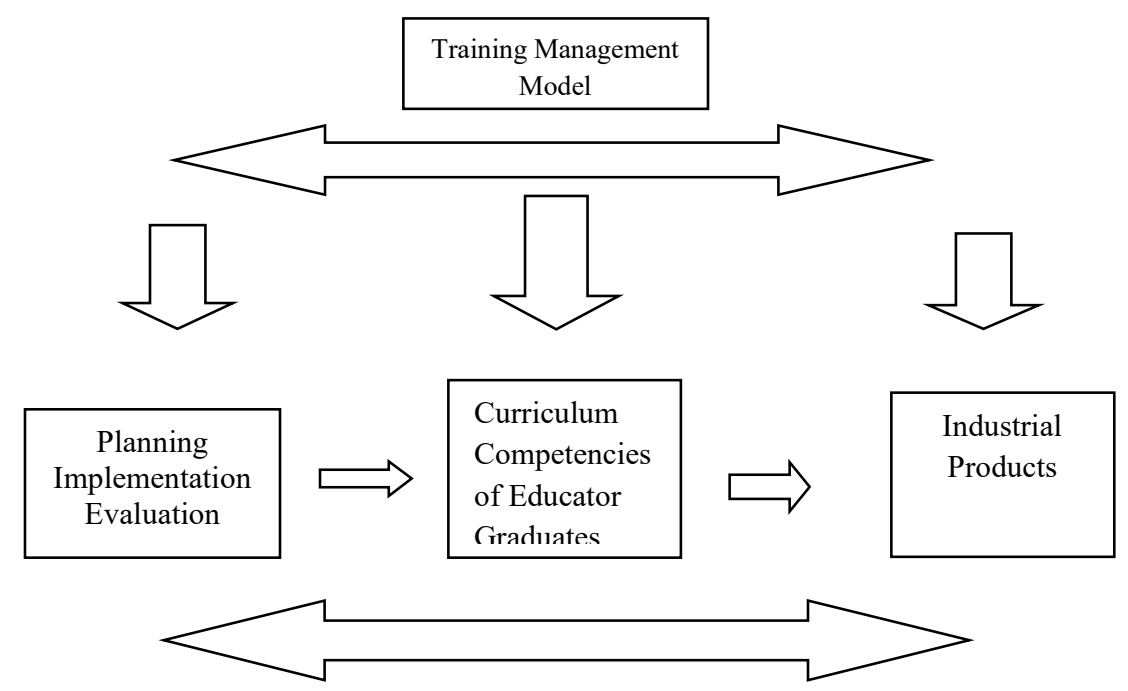

Fig 2. Training Model Management

\section{Conclusion}

1. The theoretical design of management training in the Unimed Diploma 3 Mechanical Engineering Study Program has led to the concept of BLK as an organizational concept but not yet. However, to improve student competency in designing products, certain training 
models are needed, because training requires a certificate of competency test results as a companion diploma. To improve student competency in product design, well-organized training is needed, starting from planning, organizing, implementing, to controlling. Existing management training must also be adjusted to the National Level Work Qualification Standards (SKKNI) Level 5 Subdivision Training Methodology. The facilities and facilities that support training in the Unimed Diploma in Mechanical Engineering Three Study Programs are quite complete, namely by having sufficient machining tools to used by all students in one class, totaling approximately 15 people. The workshop / workshop room is also spacious and far from noise, and is able to reduce the noise from the workshop. Basically the training has been going well, but a number of things that must be developed are the making of practicum modules, with the aim that students can design production machines more directed

2. The results of the validity of the training management model in the Universitas Negeri Medan D3 Mechanical Engineering Study Program included in the category are feasible and valid to be applied to students. Training management in Diploma Three of Mechanical Engineering, Faculty of Engineering, State University of Medan can be seen that management training shows that planning and implementation are included in the already good category. All have been carried out in accordance with what has been expected by the study program. Although overall it can be said to be in a good category but in its implementation there are still some deficiencies in certain aspects.

3. The implementation of the training management model in the Unimed Diploma 3 in Mechanical Engineering Study Program is in accordance with the planned steps and procedures. the implementation of the training management model went well this was seen from several aspects including the achievement of targets, product completion time, and customer satisfaction. As confirmed by the results of the interview, it has been going well, but there are some program evaluations that must be carried out by involving all management parties, including study programs, heads of production units, lecturers, students and staff in order to improve quality.

\section{References}

[1] BPS Ketenagakerjaan Indonesia. Berita Resmi Statistik Keadaan Ketenagakerjaan Indonesia (2018).

[2] Mohamad, M.M., Muhammad S.S., and Adnan A. The Need in Training and Retraining for TVET Teachers in Malaysia, Journal of Technical Education and Training, 1(5), (2011).

[3] Nawangwulan, Sri. Analisis Kebutuhan dan Pengembangan Sumber daya Manusia Analysis Of Training Needs and Human Resource Development. Jurnal Manajemen Kesehatan RS Dr. Soetomo,4(1), (2018).

[4] Novetra, Rheina. Hubungan Pendidikan dan Pelatihan dengan Kinerja Pegawai Negeri Sipil Di Badan Kepegawaian Daerah Provinsi Kalimantan Timur. Jurnal Administrasi Negara, 5(1), (2017).

[5] Purnamawati. Peningkatan Kemampuan Melalui Pelatihan Berbasis Kompetensi (Competency-Based Training) Sebagai Suatu Proses Pengembangan Pendidikan Vokasi. Jurnal MEDTEK, (2011). 
